\title{
F O V ACHESON AND MAORI CUSTOMARY LAW
}

\author{
$R$ P Boast
}

Frank Acheson, ${ }^{1}$ Judge of the Wanganui and later of the Tai Tokerau Divisions of the Native Land Court, was a remarkable individual and one of the Victoria Law Faculty's more unusual graduates. Acheson was born at Riverton, Southland, and his LLB was obtained at Otago University, but in 1912 he and his wife Flora moved to Wellington. Acheson worked as a civil servant while studying for his LLM at Victoria University College, which he obtained in 1913.

It was in 1913, after the conferment of his LLM, that Frank Acheson wrote the long essay for the Jacob Joseph Scholarship at Victoria University from which this reprint is taken. This essay was written before Acheson began his career in the Native Department. Acheson seems in fact to have been drawn to working in the Native Department because he was intellectually interested in Maori customary law, rather than the other way round. Exactly why, and how, Acheson became fascinated by Maori customary law is something of a mystery (it seems an unusual avocation for a Southlander educated at the University of Otago). However for a short period before moving to Wellington Acheson had lived in Wanganui, and it may be that it was the obvious Maori presence in that city, so different from the towns and cities of Otago and Southland, which awakened an interest which was to absorb him for the rest of his life.

The Jacob Joseph Scholarship essay is 94 pages long and comprises eight chapters. ${ }^{2}$ The first two, the introduction, and "The Strong Arm" are reprinted here. The remaining chapters are detailed studies of five areas of Maori custom: ohaaki (verbal wills), adoptions, captivity,

* Senior Lecturer in Law, Victoria University of Wellington.

1 For fuller biographical details see J Acheson and R P Boast, "Acheson, Frank Oswald Victor: Clerk, land purchase officer, land court judge, writer", Dictionary of New Zealand Biography, vol 4, Auckland, 1998, $1-3$.

2 The full title of the essay is "The Ancient Maori System of Land Tenures (Some Few Aspects Of): Being a Thesis written for the Jacob Joseph Scholarship, 1913, Victoria University College, Wellington". 
vassalage and gifts. These discussions are mainly illustrated with references from the minute books of the Native Land Court. The first two chapters are of particular jurisprudential and historical interest, for it is here that Acheson challenges the intellectually ascendant legal positivism of the day.

Acheson does not himself use the term "Maori customary law", and he in fact denies that Maori had "laws" at all ("strictly so called"). But in his insistence that Maori society was not governed by "the strong arm" but in fact by a comprehensive system of customary practice, Acheson comes very close to the position of contemporary legal anthropologists. If Maori customs were not laws, in an Austinian sense at least, they certainly came very close to it. What Maori law lacked, Acheson noted, was the Austinian requirement of being "posited" as a generalising command by a sovereign:

Their customs or rules with regard to land may not have been given to them by a determinate superior, individual or composite, to whom they rendered habitual obedience. Nevertheless, comparing the two states of civilisation, the customs of the Maoris were as much enforced in New Zealand as were the laws of our own nation in England during the early days of the race.

As the above passage shows, Acheson places the emphasis on enforcement rather than on the commands of an all-powerful sovereign. Maori had, he says, "no all-powerful Prince". But the customs were enforced "by such means as existed", chiefly "the general opinion of the tribe, as expressed in the meetings of the elders or through the mouth of a chief".

The dominant note of Acheson's essay is that Maori custom deserves to be taken seriously as a body of jurisprudence and is worthy of respectful study. How unusual and idiosyncratic a stance that was in New Zealand in 1913 now requires an effort of the imagination to grasp. The orthodox view is shown by the fate of an enquiry to the University of New Zealand made by Judge Gilfedder of the Native Land Court in 1916. Gilfedder wanted to know whether the Senate would receive a thesis on Maori law for the degree of Doctor of Laws. Although Professors Hight and Macmillan Brown supported the proposal, it was rejected by the Chancellor on the basis that Maori law and custom did not come within the meaning of the word "law" as used in the University statute: ${ }^{3}$

He [the Chancellor] added that all the lawyers on the law committee - the Hon J A Tole and Messrs von Haast and Ostler - quite concurred in that view. Maori law was merely folk law, or

3 "Suggested Thesis discussed by Senate", New Zealand Times, 4 February 1916 (my thanks to John Acheson for this reference). 
tribal law, or custom. It was held by many, indeed, that there was no Maori law till Judge Fenton made it.

Acheson is now mainly known for his later career as a judge of the Native Land Court. After working as a land purchase officer in the Native Department he became a judge of the Court in 1919 at the early age of 32. From 1919-24 he was judge of the Aotea Division of the Court, based at Wanganui. In 1924 he became judge of the Tai Tokerau (Northland) Division, where he was judge until 1943. Acheson's name is now especially associated with the far North, where he is still remembered by many Maori people today. Acheson was friendly with many Maori community leaders, including Te Puea Herangi of Waikato, the Te Heu Heu family of Tuwharetoa, and especially with Northland leaders such as Whina Cooper and Eru Thaka.

Acheson's judicial decisions are buried in the minute books of the Native Land Court, which never has (and still does not) publish its decisions. An examination of Acheson's judgments reveals, however, that his interest in Maori customary law remained strong. Perhaps this is most pronounced in his judgment in the Lake Omapere case of 1929 where Acheson accepted unhesitangly that Maori iwi owned lake beds under Maori customary law and that the Land Court should accordingly issue titles to lake beds. ${ }^{4}$ To Acheson Maori title to all land was presumed and the Crown had to prove lawful extinguishment of Native title, which is essentially the modern law, but which was confused at the time by Crown reliance on prerogative claims to the foreshore and lakebeds and by a sense that Maori rights to land were only cognisable when recognised in statute. Acheson was also very willing to allow Maori claims to areas of foreshore, ${ }^{5}$ and combined this willingness with an attitude towards government policies and actions which was scathingly critical, to put it mildly.

4 Lake Omapere Case (1929) Bay Islands MB 253.

5 On the Northland foreshore cases see R.P. Boast, "In re Ninety Mile Beach Revisited : The Native Land Court and the Foreshore in New Zealand Legal History" (1993) 23 VUWLR 145. This gives full references to Acheson's foreshore decisions which are now difficult to locate. Some of Acheson's decisions are known only through the accident of newspaper publication, as in the case of his Lake Tangonge decision, reported in the New Zealand Herald, 9 March 1933 (the decision was presumably oral only, and is not recorded in the Northland Minute Books of the Native Land Court). In Tangonge, saved from limbo by mere luck, Acheson (a) states that "the native title to papatupu [uninvestigated] land must be taken into account unless it could be shown that it was extinguished"; and (b) that the Treaty of Waitangi had been recognised by imperial statutes and by the Land Claims Ordinance of 1841 and that as a result "it was the duty of the Court to take judicial notice of the Treaty of Waitangi". No modern Court has in fact gone as far as Acheson on the latter point. 
Above all, however, Acheson was an activist judge. He was shocked by the poverty and isolation of the Maori communities of Northland. Even before Sir Apirana Ngata's legislation of 1929, which greatly expanded the powers and functions of Maori Land Boards and the Native Land Court, Acheson had become involved in a number of elaborate development projects designed to benefit the destitute Maori communities of Te Aupouri. It was these projects, especially the elaborate and costly scheme to develop dairy-farming on Maori freehold at $\mathrm{Te}$ Kao, which was ultimately to prove his undoing.

While working as a judge Acheson continued to write and publish. In 1922 he published a reworked version of a chapter of the 1913 essay in the Journal of Comparative Legislation and International Law. ${ }^{6}$ In 1931 he published an article on "Maori Land Customs and Education" in a collection of essays edited by P.M. Jackson. ${ }^{7}$ The 1931 article is a condensation of the 1913 essay, as the following passage makes clear: ${ }^{8}$

[A]lthough the Maoris had not studied and digested Austin's Lectures on Jurisprudence, nevertheless they knew that, if a man's ancestors had lived on a certain piece of land for many generations and had cultivated it, that man had a claim to the land, and a claim which the other members of the tribe, from the chief downward, would respect. It mattered not to the Maoris whether it was binding Native Custom or the power of a mighty Prince which maintained them in their rights to land - it was sufficient for them to know that for many generations the rights of their fathers had been respected, and that so the rights of their descendants would, in the ordinary course of events, be respected in days to come.

Acheson ventured into other fields of literature as well, and in 1930 he published a novel, Plume of the Arawas. It sold well and can still be found in second-hand bookshops. The novel is a romantic adventure story, and is saturated with Acheson's romanticised and highly-coloured vision of pre-European Maori life. ${ }^{9}$

6 F O V Acheson, "Adoption among the Maoris of New Zealand", (1922) 4 Journal of Comparative Legislation and International Law, $\left(3^{\text {rd }}\right)$ 60-70.

7 F O V Acheson, "Maori Land Customs and Education: Their Inter-Relation", in P M Jackson (ed), Maori and Education: Or the Education of Natives in New Zealand and its Dependencies, Ferguson \& Osborn, Wellington, 1931, 133-143.

8 Above $\mathbf{n} 7,138$.

9 Michael King has noted Acheson's "romantic idealisation of Maori life" in Plume of the Arawas : see Michael King, Whina (Penguin Books, Auckland, 1991) 128. 
Acheson was politically conservative and had little time for the Labour Party and the Labour Native Affairs Ministers, Frank Langstone and H G R Mason. Acheson was committed to the Treaty of Waitangi as a constititutional text (in fact he said that he could take "judicial notice" of the Treaty) and was deeply involved in the preparations for the 1940 commerations held at Waitangi. Acheson's last years as a judge were clouded by growing official disquiet at his pro-Maori stance and with an unfortunate feud with his registrar. The particular issue was the financing of the Te Kao dairy scheme, but this was merely symptomatic of disagreements at a much deeper level. In 1943 he was compulsorily retired by Mason and returned to Southland where he died in 1948.

In retrospect Acheson seems something of a tragic figure. New Zealand society was inhospitable to someone of his interests and enthusiasms. He seems to have felt much more at home in Maori society than in the company of Pakeha New Zealanders, and had little intellectual support for his views on Maori customary law from academics and lawyers. He was cut off from new developments in anthropology and jurisprudence in the United States which took decades to percolate through New Zealand's provincial Anglocentrism. As a judge Acheson faced the hostility of his own registrar, and in the foreshore and other cases determined opposition from the Crown. Maori appearing in the Court were too poor to afford lawyers of their own, and Acheson was rarely able to gain much assistance from sympathetic counsel. In court his main antagonist was the formidable Crown Solicitor at Auckland, Sir Vincent Meredith, who regarded Acheson as "very pro-Maori",10 and who routinely appealed Acheson's rulings to the Maori Appellate Court.

After his death Acheson was for many years a forgotten figure. With the Waitangi Tribunal investigations into the Orakei, Te Roroa, and Muriwhenua Lands claims the importance of Acheson's work at last began to receive long-overdue recognition. It is hoped that this publication of a sample of Acheson's early writing will also help to restore Acheson to his proper prominence. His essay shows also that the development of New Zealand jurisprudence is not necessarily as simplistic and narrowly positivist as is sometimes assumed.

10 Sir Vincent Meredith's autobiography, A Long Brief: Experiences of a Crown Solicitor, (Collins, Auckland, 1966. At 30, obviously referring to Acheson, Meredith he writes that "some matters in connection with the ownership of Maori land necessitated going to the most outlandish places. These were generally heard before a Maori land court judge who was very pro-Maori, and insisted that the hearing should be heard amongst the people - that is, on the particular spot which was the subject of dispute." 
